\title{
INHIBITOR PERTUMBUHAN Pyricularia oryzae DENGAN EKSTRAK CAIR DAUN PRONOJIWO (Euchresta horsfeildii) SECARA IN VITRO
}

\author{
Astini ${ }^{1}$ dan T. Sopandi ${ }^{2}$ \\ ${ }^{1}$ Mahasiswa Prodi Biologi, Fakultas MIPA Universitas PGRI Adi Buana Surabaya \\ ${ }^{2}$ Staf pengajar Prodi Biologi, Fakultas MIPA Universitas PGRI Adi Buana Surabaya \\ Email: tatang.sopandi1963@gmail.com
}

\begin{abstract}
Has been done research that aims to test the inhibitory power of pronojiwo (Euchresta horsfieldii) leaf extract to the fungus P.oryzae. the experimental study was conducted using a completely randomized design with 9 concentrations of liquid extract of pronojiwo leaf and 1 control. Ie the concentration of each pepeated 4 times and in duplo. Application is done by the method of well by means of liquid extract dripped on the diffusion well, dilusion method by means of liquid extract mixed on the media PDA, method of calculating the amount of fungus conidia by means of liquid extract mixed with media PDB, to determine the inhibition zone of the fungus, the growth of the diameter of the fungus, the number of living conidia. Observations were made after incubation for 7 days. The results showed that liquid extract pronojiwo leaves can inhibit and reduce the growth of fungus P.oryzae, at a concentration of $6,25 \%$ with a resistor zone result of $0,9 \mathrm{~mm}$, a growth diameter percentage of $71,2 \%$, and may reduce by 2,9 conidia/ml.
\end{abstract}

Keywords : pronojiwo leaves, growth, reduce, fungus P.oryzae

\section{Pendahuluan}

Produktivitas padi di Indonesia rata-rata adalah 4.56 ton/ha yang relatif lebih rendah dibandingkan produktivitas padi negara lain, seperti Australia, 8.22 ton / ha; Jepang, 5.85 ton/ha dan China 6.06 ton / ha (USDA, 2004). Faktor yang mempengaruhi rendahnya produktivitas tanaman padi adalah adanya penyakit bercak daun yang disebabkan oleh cendawan

Pyricularia oryzae dan banyak di temukan di daerah beriklim tropis (Kato, 2001).
Penurunan produksi padi akibat serangan cendawan dapat dikurangi dengan mengetahui karateristik cendawan dan penyakitnya serta mencari cara yang efektif dalam mengendalikannya (Widiarta, 2005).

Penggunaan pestisida nabati yang berasal dari tanaman saat ini merupakan alternatif petani untuk mengendalikan penyakit bercak daun pada padi (Indriyani, 2011). Pada penelitian ini akan menggunakan daun Pronojiwo (Euchresta horsfeildii) yang merupakan salah satu tanaman yang 
berpotensi sebagai pestisida nabati. Namun demikian, penelitian mengenai efektifitas daun pronojiwo terhadap penyakit bercak daun padi oleh cendawan Pyricularia oryzae belum banyak dipublikasikan. Oleh sebab itu penelitian ini bertujuan untuk menguji efektifitas ekstrak cair daun pronojiwo (Euchresta horsfeildii) terhadap pertumbuhan dan mereduksi cendawan Pyricularia oryzae.

\section{METODE PENELITIAN}

Penelitian

mengenai konsentrasi ekstrak cair daun pronojiwo terhadap cendawan P.oryzae, dilakukan sebagai upaya untuk menghambat dan mereduksi cendawan P.oryzae telah dilakukan secara eksperimental di UPT. Proteksi Tanaman Pangan Dan Hortikultura, Dinas Pertanian Provinsi Jawa Timur, Jalan Pagesangan II No. 58, Surabaya.

\section{Ekstrak Cair}

Sebanyak $3 \quad \mathrm{~kg}$ daun pronojiwo yang sudah dibersihkan, dikering-anginkan dan dimasukkan dalam oven dengan suhu $70-80^{\circ} \mathrm{C}$ sampai beratnya konstan. Daun pronojiwo kering ,digiling, serbuk daun pronojiwo dibagi 9 dengan konsentrasi $0 \%(\mathrm{~b} / \mathrm{v}), 1,25 \%(\mathrm{~b} / \mathrm{v})$, $2,5 \%(\mathrm{~b} / \mathrm{v}), 3,75 \%(\mathrm{~b} / \mathrm{v}), 5 \%(\mathrm{~b} / \mathrm{v})$, $6,25 \% \quad(\mathrm{~b} / \mathrm{v}), \quad 7,5 \% \quad(\mathrm{~b} / \mathrm{v}), \quad 8,75 \%$ $(\mathrm{b} / \mathrm{v}), 9,5 \%(\mathrm{~b} / \mathrm{v})$ dimaserasi selama 3 hari, jika pelarutnya menggunakan air maka ditambahkan etanol minimal $10 \%$, selain sebagai pengawet, juga untuk memudahkan penguapan maserat. Jadi hari ke satu menggunakan $40 \mathrm{ml}$ aquades yang telah dicampur etanol $10 \%$ kemudian di saring dengan kain untuk diambil ekstraknya, hari kedua dan ketiga menggunakan $30 \mathrm{ml}$ pelarut yang sama setelah itu disaring lagi. Hasil saringan atau ekstrak cair pada hari ke satu, kedua, dan ketiga dicampur menjadi satu, hingga jumlah keseluruhan yang didapat yaitu $100 \mathrm{ml}$ ekstrak cair daun pronojiwo, disimpan pada suhu kamar.

\section{Uji Aktifitas Anti Fungi} Ekstrak Cair Daun Pronojiwo dalam Pertumbuhan Cendawan P.oryzae

a. Zona hambat Cendawan $P$. oryzae dengan Metode Sumuran pada Media PDA

Sebanyak $600 \mathrm{ml}$ media PDA disterilisasi pada suhu $121^{\circ} \mathrm{C}$ selama 15 menit dengan tekanan 1 atmosfer, dibagi menjadi 10 kelompok dalam 40 cawan petri masing-masing $15 \mathrm{ml}$, diameter cawan petri yang digunakan yaitu 9 $\mathrm{cm}$. Setelah media padat, media tersebut diberi lubang dengan diameter $0,5 \mathrm{~cm}$, dan diisi $0,1 \mathrm{ml}$ ekstrak cair dengan masing-masing konsentrasi $(0 \%, 1,25 \%, 2,5 \%$, $3,75 \%, 5 \%, 6,25 \%, 7,5 \%, 8,75 \%$, $9,5 \%$, kontrol 1,5\%). Disampingnya diberi jarak 2,5 $\mathrm{cm}$ untuk diinokulasikan cendawan $P$. oryzae dengan diameter $0,5 \mathrm{~cm}$. Selanjutnya diinkubasi selama 7 hari untuk diamati zona hambatnya. 
b. Diameter Pertumbuhan Cendawan $P$. oryzae dengan Metode Dilusi pada Media PDA

Sebanyak $600 \mathrm{ml}$ media PDA disterilisasi pada suhu $121^{\circ} \mathrm{C}$ selama 15 menit dengan tekanan 1 atmosfer, dibagi menjadi 10 kelompok dalam 40 cawan petri masing-masing $15 \mathrm{ml}$, diameter cawan petri yang digunakan yaitu 9 $\mathrm{cm}$. Dalam keadaan hangat setiap kelompok media PDA tersebut ditambah ekstrak cair daun pronojiwo sebanyak $1 \mathrm{ml}$ dengan masing-masing konsentrasi $(0 \%$, $1,25 \%, 2,5 \%, 3,75 \%, 5 \%, 6,25 \%$, $7,5 \%, 8,75 \%, 9,5 \%$, kontrol 1,5\%). Selanjutnya media yang sudah memadat, di tengah-tengahnya diberi isolat cendawan P.oryzae dengan cara diinokulasikan. Agar ukuran sama, diameter yang digunakan yaitu $0,5 \mathrm{~cm}$. Setelah itu diinkubasi selama 7 hari untuk diamati diameter pertumbuhannya.

\section{Uji Aktivitas Anti Fungi} Ekstrak Cair Daun Pronojiwo dalam Mereduksi Jumlah Konidia Cendawan P. oryzae

Sebanyak $320 \mathrm{ml}$ media PDB cair disterilisasi pada suhu $121^{\circ} \mathrm{C}$ selama 15 menit dengan tekanan 1 atmosfer, dibagi menjadi 10 kelompok dalam 40 tabung reaksi masing-masing $8 \mathrm{ml}$, setiap kelompok ditambah ekstrak cair daun pronojiwo sebanyak $1 \mathrm{ml}$ dengan masing-masing konsentrasi $(0 \%, 1,25 \%, 2,5 \%, 3,75 \%, 5 \%$,
$6,25 \%, 7,5 \%, 8,75 \%, 9,5 \%$, kontrol $1,5 \%$ ), dan ditambah $1 \mathrm{ml}$ isolat $P$. oryzae yang mengandung 106. Seluruh inokulan diinokulasi pada suhu kamar selama 7 hari. Setelah 7 hari jumlah konidia di hitung menggunakan haemocytometer dan diberi pewarnaan metielin blue.

\section{Metode Analisis Data}

Data pengamatan dari perhitungan zona hambat, diameter pertumbuhan cendawan, jumlah konidia cendawan dianalisis menggunakan analisis varian satu arah (ANAVA) dengan selang kepercayaan 0,05. Apabila terdapat perbedaan yang sinifikan maka dapat dilanjut dengan uji BNT.

\section{HASIL PENELITIAN}

1. Uji Aktifitas Anti Fungi Ekstrak Cair Daun Pronojiwo dalam Pertumbuhan Cendawan P.oryzae

a. Zona Hambat Pertumbuhan

Cendawan $P$. oryzae

Hasil penelitian ini bahwa ekstrak cair daun pronojiwo berpengaruh sinifikan untuk menghambat zona pertumbuhan cendawan P.oryzae. Konsentrasi ektrak cair 6,25\%, 7,5\%, 8,75\%, $9,5 \%$ berbeda nyata dengan konsentrasi $0 \%, 1,25 \%, 2,5 \%$, $3,75 \%, \quad 5 \%, \quad 1,5 \%$. Konsentrasi $6,25 \%, \quad 7,5 \%, \quad 8,75 \%, \quad 9,5 \%$ menunjukkan hasil yang baik yaitu antara $0,9 \mathrm{~mm}$ sampai $1 \mathrm{~mm}$, seperti pada (Gambar1). 


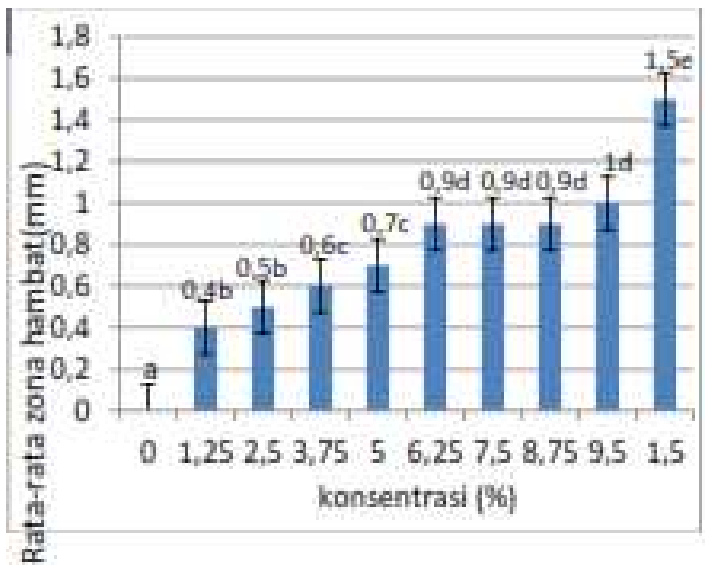

Gambar 1. Zona hambat pada cendawan P.oryzae, angka rata-rata yang diberi notasi huruf sama menunjukkan tidak berbeda signifikan $(\mathrm{P}>0,05)$.

\section{b.Persentasi Diameter} Pertumbuhan Cendawan P.oryzae

Hasil memperlihatkan bahwa aplikasi ekstrak car daun pronojiwo berpengaruh sinifikan terhadap pertumbuhan cendawan P.oryzae. Konsentrasi ektrak cair 6,25\%,
$7,5 \%, 8,75 \%, 9,5 \%$ berbeda nyata dengan konsentrasi $0 \%, 1,25 \%$, $2,5 \%, \quad 3,75 \%, \quad 5 \%, \quad 1,5 \%$. Konsentrasi $6,25 \%, 7,5 \%, 8,75 \%$, 9,5\% menunjukkan hasil persentasi yang baik yaitu antara $71,2 \%$ sampai 74,2\%, seperti pada (Gambar 2).

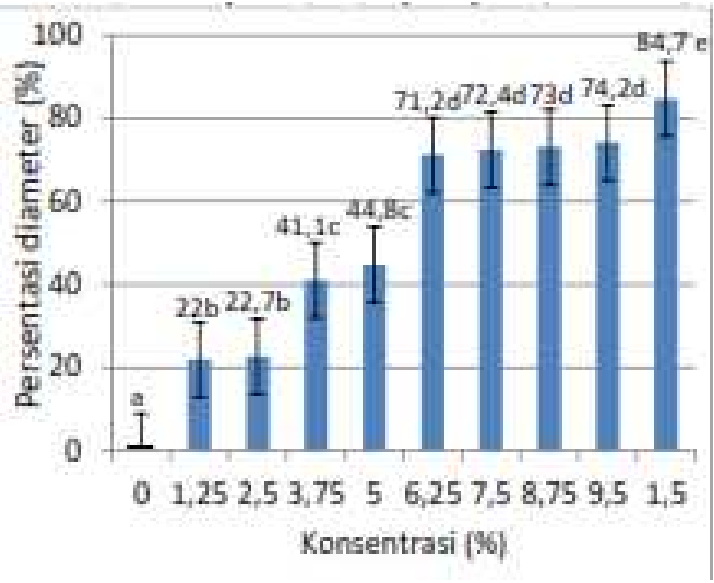

Gambar 2. Persentasi diameter pertumbuhan cendawan P.oryzae, angka ratarata yang diberi notasi huruf sama menunjukkan tidak berbeda signifikan $(\mathrm{P}>0,05)$ 
2. Uji Aktivitas Anti Fungi Ekstrak Cair Daun Pronojiwo dalam Mereduksi Jumlah Konidia Cendawan P. oryzae

Hasil penelitian memperlihatkan bahwa aplikasi daun pronojiwo berpengaruh sinifikan dalam mereduksi jumlah konidia. Konsentrasi ektrak cair
$6,25 \%, 7,5 \%, 8,75 \%, 9,5 \%$ berbeda nyata dengan konsentrasi $0 \%$, $1,25 \%, 2,5 \%, 3,75 \%, 5 \%, 1,5 \%$. Konsentrasi $6,25 \%, 7,5 \%, 8,75 \%$, 9,5\% menunjukkan hasil yang baik yaitu antara 2,9 sampai 2,8 konidia/ml, seperti pada (Gambar $3)$.

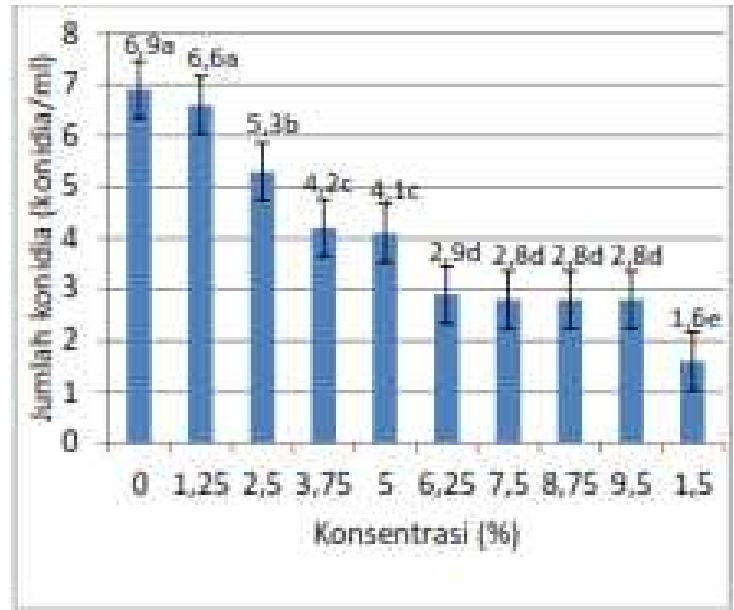

Gambar 3. Jumlah konidia pada ekstrak cair, angka rata-rata yang diberi notasi huruf sama menunjukkan tidak berbeda signifikan $(\mathrm{P}>0,05)$

\section{PEMBAHASAN}

Hasil penelitian ini mengindikasikan bahwa ekstrak cair daun pronojiwo dapat menghambat dan mereduksi pertumbuhan cendawan $P$. oryzae. Ekstrak cair daun pronojiwo dapat menghambat dan mereduksi cendawan $P$. oryzae karena daun pronojiwo mengandung fenol, flavonoid, alkaloid. Pengaruh senyawa fenol dapat mendenaturasi ikatan protein pada membran sel sehingga membran sel lisis dan fenol dapat menembus ke dalam inti sel. Masuknya fenol ke dalam inti sel inilah yang menyebabkan jamur tidak berkembang (Sulistyawati dan Mulyati, 2009).

Senyawa flavonoid berperan sebagai antifungi, flavonoid mempunyai senyawa genestein yang berfungsi menghambat pembelahan atau proliferasi sel. Senyawa ini mengikat protein mikrotubulus dalam sel dan mengganggu fungsi mitosis gelendong sehingga menimbulkan penghambatan 
pertumbuhan jamur. (Roller, 2003; Siswandono dan Soekardjo, 2000).

Senyawa alkaloid mempunyai aktivitas antifungi dengan menghambat esterase, DNA, RNA polimerase, dan respirasi sel serta berperan dalam interkalasi DNA (Aniszewki, 2007). Sebagai antifungi, alkaloid menyebabkan kerusakan membrane sel. Alkaloid akan berikatan kuat dengan ergosterol membentuk lubang yang menyebabkan kebocoran membran sel. Hal ini mengakibatkan kerusakan dan kematian sel pada jamur (Mycek et al, 2001; Setiabudy dan Bahry, 2007).

Penelitian ini didukung dengan penelitian lain yang dilakukan oleh A. Hoiri dan Sopandi (2013) berdasarkan penelitiannya melaporkan bahwa, daun pronojiwo mengandung alkaloid, flavonoid, dan fenol, penelitian ini mengindikasikan pada aplikasi ekstrak air daun pronojiwo dengan konsentrasi 100 $\mathrm{g} / \mathrm{l}$ dapat menyebabkan persentase mortalitas sebesar $80 \%$ terhadap hama padi $N$. lugens, $T$. innotata dan L. Acuta.Suriani, et al. (2015) juga menunjukkan bahwa senyawa alkaloid, flavonoid dan fenol yang terkandung dalam ekstrak Piper caninum mampu menghambat pertumbuhan cendawan P.oryzae sebesar $5,44 \mathrm{~mm}$ pada konsentrasi 3,5\%. Menurut penelitian Gandalera et al. (2013), ekstrak Chaetomium globosum Kunze mampu

menghambat pertumbuhan cendawan P.oryzae sebesar 29,90 mm pada konsentrasi 1000 ppm.

Hal ini didapatkan dari penelitan yang menunjukkan bahwa konsentrasi yang paling efektif dalam pembuatan fungisida nabati daun pronojiwo adalah $6,25 \%$, $7,5 \%, 8,75 \%, 9,5 \%$, konsentrasi tersebut memiliki hasil yang tidak berbeda nyata, sehin gga untuk pembuatan fungisida daun pronojiwo yang paling baik yaitu menggunakan konsentrasi $6,25 \%$, karena bahan yang digunakan hanya sedikit dan tidak membutuhkan bahan banyak, hasil yang didapat pada konsentrasi $6,25 \%$ untuk zona hambat sebesar $0,9 \mathrm{~mm}$, persentasi penghambatan diameter pertumbuhan sebesar $71,2 \%$, dan dapat mereduksi sebesar 2,9 konidia/ml, sehingga hasil yang didapat tidak berbeda nyata dengan konsentrasi 9,5\%. Jadi konsentrasi tinggi belum tentu menunjukan hasil yang lebih baik. Jika dari penelitian ini, konsentrasi ekstrak cair daun pronojiwo $6,25 \%$ dibandingkan dengan kontrol 1,5\% memiliki hasil yang berbeda nyata, kontrol tersebut menggunakan fungisida kimia. Hasil yang didapat dari fungisida kimia lebih baik jika dibandingkan dengan fungisida nabati dari daun pronojiwo, karena fungisida kimia didalamnya terdapat bahan aktif yaitu 
propikanazol dan trisiklazol, dimana bahan aktif tersebut memiliki anti fugi. Propikanazol berfungi untuk mengaktifkan sistem pertahanan penyakit tanaman padi dengan merubah hubungan tanamanpatogen menjadi hubungan yang menguntungkan bagi tanaman padi. Mekanisme kerja bahan ini tidak mengganggu metabolisme pertumbuhan tanaman padi, yang mengaktifkan enzim phenilalanine ammonia-lyase, peroksidase dan polyphenoloksidase sebagai barier bagi kerja jamur penyebab bercak padi. Trisiklazol merupakan bahan aktif yang berfungsi secara sistemik mengendalikan jamur penyebab bercak pada padi. Cara kerjanya adalah menghambat perkembangan spora jamur penyebab penyakit.

\section{KESIMPULAN}

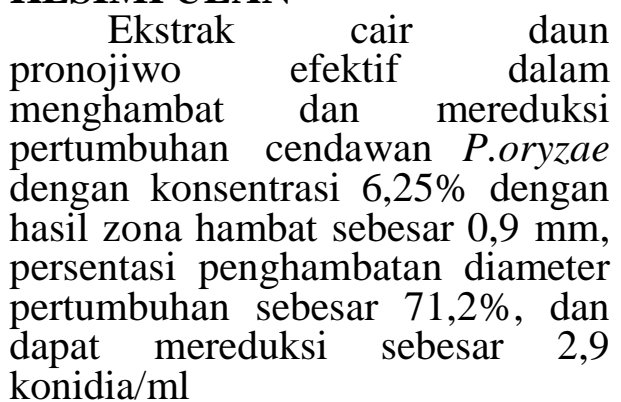

\section{DAFTAR PUSTAKA}

A.Hoiri dan T. Sopandi (2013). "Konsentrasi Letal Ekstrak Daun Pronojiwo (Euchresta Horsfieldii) terhadap Tiga Serangga Hama Padi Wereng Coklat (Nilaparvato lugens),
Walang sangit (Leptocorisa acuta) dan Penggerek Batang (Tryporiza innotata), vol.6, no.02.

Chen, D. 1993. "Population Structure of Pyricularia grisea (Cooke) Sacc. In Two Screening Site and Quantitative

Characterization of Major and Minor Resistance Genes". A Thesis Doctor of Philosophy. Los Banos: University of the Philippines at. 161p.

Dadang. $1999 . \quad$ Sumber Insektisida Alami. http://fp.unram.ac.id/data/ Karya-ilmiah/ KegiatanPengabdian /materi/pelatihan.pdf.

Djunaedy A, 2009. Biopestisida sebagai Pengendali Organisme Pengganggu Tanaman Lingkungan. (Online).

Setiabudi dan Bahry, 2007. Obat Jamur. Dalam : Gunawan, S.G. Ed.2. Jakatra : Gaya Baru, pp : 574-75.

Siswandono dan Soekarjo, B., 2000, Kimia Medisinal, Edisi 2, 228-232, 234, 239, Airlangga University Press, Surabaya.

Widiarta, I. N. 2005. Wereng Hijau (Nephotettix virescens Distant): Dinamika Populasi dan Strategi Pengendaliannya sebagai 
Vektor Penyakit Tungro

Balai Penelitian Padi, Jalan

Raya No 9, Sukamandi

Kotak Pos 11, Subang.

Jurnal Litbang Pertanian, 24(3), 2005. 